\title{
Immunohistochemical expression of Ki-67 in invasive breast carcinoma and its correlation with prognostic parameters
}

\author{
Jain $\mathbf{R}^{1}$, Malik $\mathbf{R}^{2}$, Trichal $\mathrm{VK}^{3}$, Jain $\mathrm{A}^{4}$, Bakna $\mathbf{M}^{5}$ \\ ${ }^{1}$ Dr. Rashmi Jain, P.G. Resident, Department of Pathology, ${ }^{2}$ Dr. Reeni Malik, Professor, Department of Pathology, \\ ${ }^{3}$ Dr.V.K. Trichal, Associate Professor, Department of Pathology, ${ }^{4}$ Dr. Ankit Jain, P.G. Resident, Department of \\ Anatomy, ${ }^{5}$ Dr. Minu Bakna, P.G. Resident, Department of Pathology. All are affiliated with Gandhi Medical College, \\ Bhopal (M.P.), India
}

Address for Correspondence: Dr. Rashmi Jain, Department of Pathology, Gandhi Medical College, Bhopal (M.P.), E-mail address: dr.rashmi71286@gmail.com

\begin{abstract}
Background: Ki-67 expression is strictly associated with cellular proliferation and is an excellent marker for determining the growth fraction of a given cell population. It may be considered as alternative to mitotic counts in grading schemes and as a single parameter that can be used in fine needle aspirates and small biopsies. The aim of this study was to evaluate proliferative fraction of Ki67 expression in invasive breast carcinoma and to find out the correlation between Ki67 expression and clinico-pathological prognostic factors such as tumor size, lymph node status, histological grade and Nottingham prognostic index. Materials and Methods: Seventy cases of infiltrating ductal carcinoma breast were studied. Immunohistochemistry using the anti-Ki-67 antibody [MIB-1] was performed on all cases and Ki-67 staining was categorized as low and high grade. Result: High expression of Ki-67 was found in $71.05 \%$ cases of breast tumor with positive lymph node metastasis and $92.31 \%$ cases of Grade III tumor. Ki-67 expression was significantly associated with nodal status $(\mathrm{p}<0.0001)$ and poorly differentiated tumor $(\mathrm{p}<0.0001)$. Although, Ki-67 expression was associated with tumor size, but their correlation was not statistically significant $(\mathrm{p}=0.065)$. Conclusion: High Ki-67 expression was associated with a higher grade of malignancy. Conclusively, proliferative activity determined by Ki-67 expression may reflect the aggressive behavior of breast carcinoma. Ki-67 detection provides valuable information about proliferative activity of cells so, it is necessary to combine this with other parameters for better prognosis.
\end{abstract}

Keywords: Breast carcinoma, Histological grade, Ki-67

\section{Introduction}

Carcinoma of breast is the most common malignant tumor in women. Evaluation of breast lumps is essential to identify patients with benign proliferative lesions of the breast and these benign lesions are an important risk factor for subsequent transformation to malignancy [1]. Advances in imaging techniques and the increased use of needle biopsy have greatly assisted the preoperative evaluation of breast lesions but, in a large proportion of cases, differentiation between benign and malignant lesions still rests on histological examination [2]. Prognostic factors provide information which is useful in assessing the outcome at the time of diagnosis.

Manuscript received $2^{\text {nd }}$ April 2016

Reviewed: $11^{\text {th }}$ April 2016

Author Corrected: $20^{\text {th }}$ April 2016

Accepted for Publication $5^{\text {th }}$ May 2016
Traditional prognostic factors in patient with invasive breast cancer include lymph node status (the single most important prognostic factor), tumor size, histological type and histological grade [2]. In addition to the traditional histopathological parameters, the assessment of proliferation is the most important factor for treatment decisions in breast cancer patients [3]. A wide range of techniques are available to assess tumor cell proliferation such as percentage of cells in mitosis, thymidine or Bromodeoxyuridine (BRDU) labeling index, $\mathrm{S}$ phase fraction measurement, examination of proliferating cell nuclear antigen (PCNA) and immunostaining with antibodies to Ki-67 [2,4,5]. Ki-67 antigen is a huge nonhistone nuclear protein of approximate $395 \mathrm{kDa}$, encoded for almost 30,000 base 
pairs within the human genome [6]. Ki-67 protein was originally defined by the prototype monoclonal antibody Ki-67. Ki-67 monoclonal antibody was generated by immunizing mice with nuclei of the Hodgkin's lymphoma cell line L428 [7]. Ki-67 nuclear antigen is being associated with cellular proliferation. Except G0 phase, it is expressed in S, G1, G2, and M phases of the cell cycle [8]. The most prevalent analysis method of Ki-67 antigen is the immunohistochemical evaluation [9]. Ki-67 values are defined as the percentage of positively marking malignant cells using the antihuman Ki-67 monoclonal antibody MIB-1 which is the most commonly used antibodies and considered as the "gold standard" [10]. Growth fraction of neoplastic cell populations is assessed by immunostaining with Ki-67monoclonal antibody. Ki-67 detection provides significant evidence of the proliferative fraction for chemotherapy decision in the early breast cancer and is used to predict the risk of recurrence and extent of chemotherapy benefits in women with node-negative ER-positive breast cancer $[11,12]$. Many studies have assessed the association between Ki-67 immunoreactivity with other prognostic factors in breast carcinomas [13, 14].

The objective of this study is to evaluate proliferative fraction of Ki67 expression in invasive breast carcinoma and to find out the correlation between Ki67 expression and prognostic markers such as tumor size, lymph node status, histological grade (Modified Bloom
Richardson Grade) and Nottingham prognostic index (NPI).

\section{Materials and Methods}

This was a retrospective study carried out in the Department of Pathology, Gandhi Medical College, Bhopal (M.P.). Seventy cases of invasive ductal breast carcinoma, not otherwise specified (IDC, NOS) after mastectomy were studied, after permission from institutional ethics committee. All cases of male breast carcinoma, carcinomas other than invasive ductal carcinoma (NOS), breast carcinoma in pregnant woman and cases exposed to radiotherapy or chemotherapy were excluded from this study. Patient's demographic data such as age, details of tumor size and lymph node status were collected from archives of our department. Paraffin blocks of the selected cases were retrieved for immunohistochemical (IHC) staining of Ki-67.

Paraffin blocks of all selected cases were processed and stained by haematoxylin and eosin staining; and reviewed for histological type and grade. Grading was done according to Modified Bloom Richardson Grade [2]. Size of the tumor was classified as pT1 $(\leq 2 \mathrm{~cm})$, pT2 (>2 cm to $\geq 5 \mathrm{~cm})$ and pT3 $(>5 \mathrm{~cm})$; and lymph node status was classified as pN0, pN1 (1-3), pN2 (4-9) and $\mathrm{pN} 3$ (>10) according to the TNM staging system. Nottingham prognostic index (NPI) was calculated in all cases as follows-

Tumor size in cm x 0.2 + lymph-node stage (I, II or III) + histologic grade (1, 2 or 3) and categorized in the following groups: A. < 3.4 (Good prognosis), B. $\geq 3.4$ and <5.4 (Moderate prognosis), C. $\geq 5.4$ (Poor prognosis).

All sections were screened and representative blocks were selected for immunohistochemical (IHC) staining. We used Biogenix USA kit for immunohistochemical (IHC) staining. 3 to $4 \mu \mathrm{m}$ thin sections were taken on slides coated with $1 \%$ poly lysine O. Sections were deparaffinised in xylene and rehydrated in absolute alcohol, 90\% alcohol and $70 \%$ alcohol. Antigen retrieval was done in pressure cooker using tri sodium citrate buffer at $\mathrm{pH}$. Sections were treated with $3 \%$ hydrogen peroxidase to quench endogenous peroxidase activity and then stained with antibodies against Ki-67 for $2 \mathrm{~h}$ (positive and negative controls were run simultaneously). The peroxidase antiperoxidase method was followed for secondary staining. DAB [3, 3'- Diaminobenzidine] was used for coloring the antigen-antibody complex.

The proportion of the malignant cells staining positive for the nuclear antigen Ki-67 was evaluated in a quantitative and visual way by using light microscope. IHC slides were initially screened under 40 magnifications, to identify areas of maximum intensity. The Ki-67 score is defined as the percentage of positively stained tumor cells among the total number of malignant cells assessed [15].

Distinct nuclear staining was taken as positive. Germinal centre of reactive lymph node was taken as positive control. A minimum five hundred cells were counted in an area of maximum Ki67 positivity and expressed as percentage. A Ki-67 cut-off point of $15 \%$ was defined according to the experience of different pathologists $[4,14,16]$. A count less than $15 \%$ was taken as low grade [Fig-1] and more than $15 \%$ was taken as high grade [Fig-2]. 

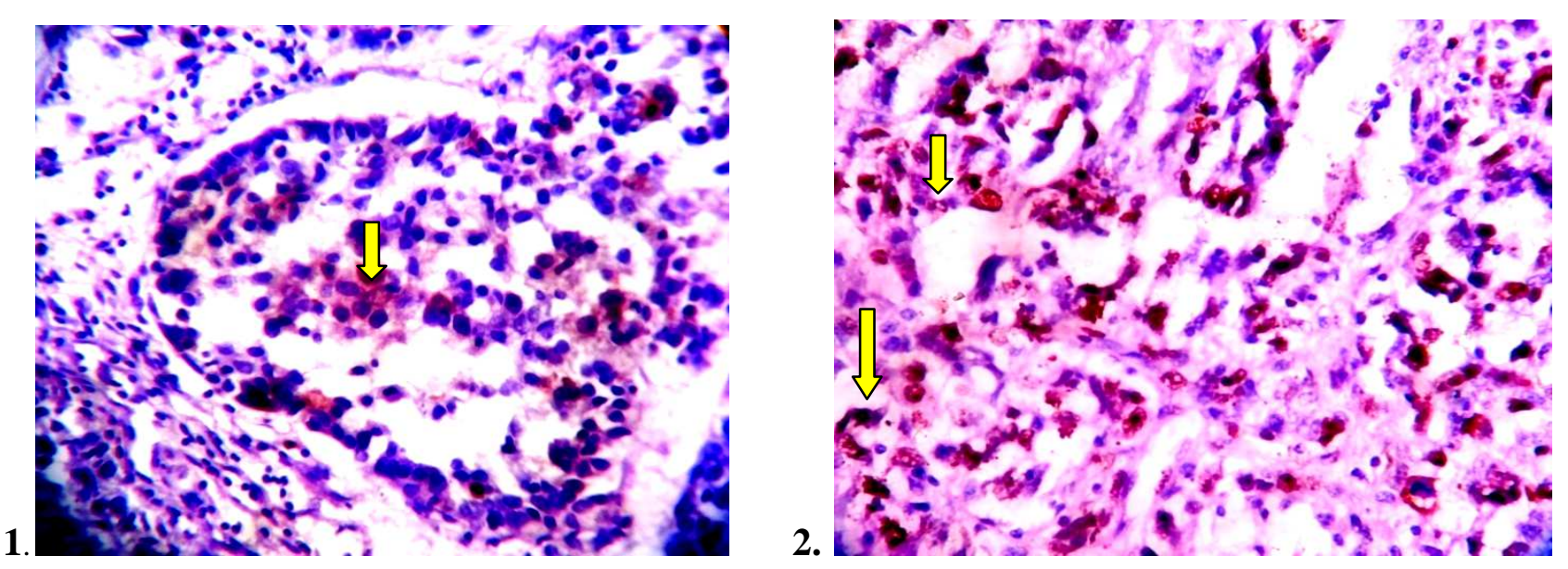

Figure 1\& 2: Immunohistochemical (IHC) staining of low Ki-67 expression ( $<15 \%$ nuclear staining) and high Ki-67 expression (>15\% nuclear staining) in figure 1 and 2 respectively. Arrow shows cells with distinct nuclear staining for Ki-67. [400x]

Statistical analysis of data was performed by using Statistical Package for Social Sciences (SPSS) version 15.0 (Chicago, IL). Categorical data were expressed as frequency counts (percentages). Statistical correlation for categorical data was done by using Chi-square test. A $P$ value $<0.05$ was considered significant.

\section{Results}

The associations between Ki-67 expression and clinico-histopathological parameters are shown in Table-1. The incidence of invasive breast carcinoma was highest (34.28\%) in the age group of 41-50 years. Expression of Ki-67 (>15\%) was

Table 1: The association between the Ki-67 expression and clinico-histopathological parameters in breast cancer $(\mathbf{n}=70)$

\begin{tabular}{|c|c|c|c|c|}
\hline \multirow{2}{*}{\multicolumn{2}{|c|}{ Clinico-histopathological parameters }} & \multicolumn{2}{|c|}{ Ki-67 expression } & \multirow[t]{2}{*}{ P value* } \\
\hline & & & & \\
\hline \multirow[t]{2}{*}{ Menstrual history } & Premenopausal & $11(39.28 \%)$ & $17(60.72 \%)$ & \multirow[t]{2}{*}{$0.039^{\mathrm{a}}$} \\
\hline & Postmenopausal & $27(64.29 \%)$ & $15(35.71 \%)$ & \\
\hline \multirow[t]{3}{*}{ Tumor size } & T1 & $3(100 \%)$ & 0 & \multirow[t]{3}{*}{$0.065^{b}$} \\
\hline & $\mathrm{T} 2$ & $18(64.28 \%)$ & $10(35.72 \%)$ & \\
\hline & T3 & $17(43.58 \%)$ & $22(56.42 \%)$ & \\
\hline \multirow[t]{5}{*}{ Lymph node } & $\begin{array}{l}\text { Negative lymph node } \\
\text { (pN0) }\end{array}$ & $27(84.37 \%)$ & $5(15.63 \%)$ & \multirow[t]{5}{*}{$<0.0001^{\mathrm{a}}$} \\
\hline & $\mathrm{pN} 1$ & $7(41.17 \%)$ & $10(58.83 \%)$ & \\
\hline & $\mathrm{pN} 2$ & $4(22.22 \%)$ & $14(77.78 \%)$ & \\
\hline & $\mathrm{pN} 3$ & 0 & $3(100 \%)$ & \\
\hline & $\begin{array}{l}\text { Positive lymph node } \\
(\mathrm{pN})\end{array}$ & $11(28.95 \%)$ & $27(71.05 \%)$ & \\
\hline \multirow[t]{3}{*}{ Tumor grade } & Grade I & $19(100 \%)$ & 0 & \multirow[t]{3}{*}{$<0.0001^{\mathrm{a}}$} \\
\hline & Grade II & $18(47.36 \%)$ & $20(52.64 \%)$ & \\
\hline & Grade III & $1(7.69 \%)$ & $12(92.31 \%)$ & \\
\hline \multirow[t]{3}{*}{ NPI score } & $<3.5$ & $17(100 \%)$ & 0 & \multirow[t]{3}{*}{$<0.0001^{\mathrm{a}}$} \\
\hline & $>3.5$ to $<5.5$ & $16(61.54 \%)$ & $10(38.46 \%)$ & \\
\hline & $>5.5$ & $5(18.52 \%)$ & $22(81.48 \%)$ & \\
\hline
\end{tabular}

*Statistical analysis of data was done by using Chi-square test. $P$ value $<0.05$ was considered significant. a. Significant, b. Not significant. \# Positive lymph node $(\mathrm{pN})$ is the sum of $\mathrm{pN} 1, \mathrm{pN} 2$ and $\mathrm{pN} 3$. 
high in $32(45.72 \%)$ cases. High expression of Ki-67 was found in $60.72 \%$ and $35.71 \%$ cases of premenopausal and postmenopausal women respectively. The correlation between menstrual history and Ki-67 expression was statistically significant $[\mathrm{p}=0.039]$. Regarding the tumor size, we observed that low $\mathrm{pT}$ stage tumors were associated with low expression of Ki-67, whereas high pT stage tumors were associated with high expression of Ki-67. But the association between Ki-67 expression and tumor size was not statistically significant $[\mathrm{p}=0.065]$. Concerning the nodal status, high expression of Ki-67 was found in $71.05 \%$ and $15.63 \%$ cases of breast tumor with positive lymph node and negative lymph node respectively. We observed that as the nodal status of the tumor increases, expression of Ki-67 was also increases. The association between Ki-67 expression and nodal status of tumor was statistically highly significant [p $<0.0001]$. We found that in Grade I tumor, all cases were associated with low Ki-67 expression, whereas in Grade III tumor, $92.31 \%$ cases were associated with high Ki-67 expression. High Ki-67 expression was significantly [p $<0.0001]$ associated with advanced stages and poorly differentiated tumor. We also found that expression of Ki-67 increases, as the NPI value increases, which means high Ki-67 expression, was associated with poor prognosis.

\section{Discussion}

Numerous studies have shown that morphological assessment of tumor differentiation provides prognostic information in the patients with breast carcinoma [17, 18]. At present, prognosis of breast carcinoma is predicted on the basis of clinicopathological parameters such as tumor size, nodal status, histological type and nuclear grade. The rate at which a tumor proliferates has been correlated with its clinical course. Histopathologists, therefore, have sought a means of determining the rate of tumor proliferation as an adjunct to diagnosis. The simplest and most established of these practices is a count of mitotic figures. The use of antibodies to Ki-67 is a reliable and easy means of accurately assessing the growth fraction of human neoplasms. A perfect correlation has been demonstrated between visual counting techniques and image analyzing systems for calculating the percentage of cells stained with Ki-67 [19]. Many authors have reported an association of Ki-67 with histological grade, lymph node status, tumor size, ER/PR status and p53status [20, 21, 22]. Ermiah E. et al found that high Ki-67 expression was associated with a higher grade of malignancy such as hormone receptor negative tumors, advanced pT stages, poor differentiation of tumors, positive axillary lymph nodes, distant metastasis and a high S -phase fraction [23]. Jacquemier et al observed that vascular and lymphatic invasion were associated with high Ki-67 expression [24]. Inwald E.C. et al also observed that high Ki-67-labeling index was associated with larger tumors, higher tumor grade, vascular invasion, and HER-2 positivity [16]. In the present study, we found that low pT stage tumors were associated with low expression of Ki-67, whereas high pT stage tumors were associated with high Ki-67 expression. We also observed that higher nodal status were significantly associated with higher Ki-67 expressions. These findings are similar to the findings reported by earlier researchers [16, 23]. Histological grading is commonly used parameter for therapy decision. Grading describes differentiation as well as proliferation in various tumors. We found that higher Ki-67 index (>15\%) was significantly correlated with a higher grade of malignancy. This correlation was proven in various former studies [16, 22, 23]. Ki-67 expression is used as a prognostic factor for both disease free survival (DFS) and overall survival (OS), irrespective of the lymph node status [25]. Inwald E.C. et al found that patients with high Ki-67 labeling index breast tumor had both worse disease free survival (DFS) and overall survival (OS) [16]. Midulla et al, observed that high level of Ki-67 expression was associated with early recurrence after mastectomy and low survival rate [26]. We found that expression of Ki-67 increases, as the NPI value increases, which means high Ki-67 expression, was associated with poor prognosis. Most of the studies were outlining the importance of Ki-67 to predict the clinical and pathological response to chemotherapy in early or locally advanced breast cancer. There is a tendency of reduction of Ki-67 value after chemotherapy [27]. Dowsett et al, observed that short term endocrine treatment may improve the disease free survival which can be predicted by measurements of Ki-67 level. This finding suggests that the Ki-67 is an important marker throughout the course of treatment [28].

\section{Conclusion}

This study confirms the value of Ki-67 evaluation as a prognostic factor being associated with breast cancer outcomes. High Ki-67 expression was associated with a higher grade of malignancy such as advanced $\mathrm{pT}$ stages, positive axillary lymph nodes and poor differentiation of tumors. Conclusively, proliferative activity determined by Ki-67 expression may reflect the aggressive behavior of breast carcinoma. Ki67 is a very 
reliable replacement for mitotic count and can be determined easily by using immunohistochemistry in tumor samples obtained by needle core biopsies and in cytologic specimens, in which there are limited number of cells present. Neoadjuvant therapy, including preoperative chemotherapy and hormonal therapy, is becoming increasingly for early breast cancer. It is desirable to grade tumors using Ki-67 labeling index before surgery so that the most appropriate medical regimen can be selected.

Funding: Nil, Conflict of interest: None initiated.

Permission from IRB: Yes

\section{References}

1. Gump FE. Premalignant diseases of the breast. The Surgical clinics of North America. 1984 Dec; 64(6) :1051-59.

2. Carter D, Schnitt SJ, Millis RR. The Breast. In: Millis SE. Sternberg's diagnostic surgical pathology. Philadelphia: Lippincott Williams \& Wilkins; 2010. p. 285-345.

3. Wirapati P, Sotiriou C, Kunkel S, et al. Meta-analysis of gene expression profiles in breast cancer: toward a unified understanding of breast cancer subtyping and prognosis signatures. Breast Cancer Res. 2008 Jan 1; 10(4):R65.

4. Stuart-Harris R, Caldas C, Pinder SE, Pharoah P. Proliferation markers and survival in early breast cancer: a systematic review and meta-analysis of 85 studies in 32,825 patients. The Breast. 2008 Aug 31; 17(4):323-34.

5. Garcia RL, Coltrera MD, Gown AM. Analysis of proliferative grade using anti-PCNA/cyclin monoclonal antibodies in fixed, embedded tissues. Comparison with flow cytometric analysis. The American journal of pathology. 1989 Apr; 134(4):733-739.

6. Schlüter C, Duchrow M, Wohlenberg C, Becker MH, Key G, Flad HD, Gerdes J. The cell proliferationassociated antigen of antibody Ki-67: a very large, ubiquitous nuclear protein with numerous repeated elements, representing a new kind of cell cyclemaintaining proteins. The Journal of cell biology. 1993 Nov 1; 123(3):513-22.

7. Gerdes J, Schwab U, Lemke H, Stein H. Production of a mouse monoclonal antibody reactive with a human nuclear antigen associated with cell proliferation. International journal of cancer. 1983 Jan 15; 31(1):1320.

8. Gerdes J, Lemke HI, Baisch HE, Wacker HH, Schwab U, Stein H. Cell cycle analysis of a cell proliferation-associated human nuclear antigen defined by the monoclonal antibody Ki-67. The Journal of Immunology. 1984 Oct 1; 133(4):1710-15.

9. Cooper LS, Gillett CE, Smith P, Fentiman IS, Barnes DM. Cell proliferation measured by MIB1 and timing of surgery for breast cancer. British journal of cancer. 1998 May; 77(9):1502-07.

10. Dowsett M, Nielsen TO, A'Hern R, Bartlett J, Coombes RC, Cuzick J, Ellis M, Henry NL, Hugh JC, Lively T, McShane L. Assessment of Ki67 in breast cancer: recommendations from the International Ki67 in Breast Cancer working group. Journal of the National Cancer Institute. 2011 Sep 29; 103: 1656-64.

11. Paik S, Tang G, Shak S, Kim C, Baker J, Kim W, Cronin M, Baehner FL, Watson D, Bryant J, Costantino JP. Gene expression and benefit of chemotherapy in women with node-negative, estrogen receptor-positive breast cancer. Journal of clinical oncology. 2006 Aug $10 ; 24(23): 3726-34$.

12. Paik S, Shak S, Tang G, Kim C, Baker J, Cronin M, Baehner FL, Walker MG, Watson D, Park T, Hiller W. A multigene assay to predict recurrence of tamoxifentreated, node-negative breast cancer. New England Journal of Medicine. 2004 Dec 30; 351(27):2817-26.

13. Railo M, Nordling S, Von Boguslawsky K, Leivonen M, Kyllönen L, Von Smitten K. Prognostic value of Ki-67 immunolabelling in primary operable breast cancer. British journal of cancer. 1993 Sep; 68(3):579.

14. Yerushalmi R, Woods R, Ravdin PM, Hayes MM, Gelmon KA. Ki67 in breast cancer: prognostic and predictive potential. The lancet oncology. 2010 Feb 28; 11(2):174-83.

15. Urruticoechea A, Smith IE, Dowsett M. Proliferation marker Ki-67 in early breast cancer. Journal of clinical oncology.2005Oct 1;23(28):7212-20.

16. Inwald EC, Klinkhammer-Schalke M, Hofstädter F, Zeman F, Koller M, Gerstenhauer M, Ortmann O. Ki- 
67 is a prognostic parameter in breast cancer patients: results of a large population-based cohort of a cancer registry. Breast cancer research and treatment. 2013 Jun $1 ; 139(2): 539-52$.

17. Davis BW, Gelber R, Goldhirsch A, Hartmann WH, Hollaway L, Russell I, Rudenstam CM, Ludwig Breast Cancer Study Group. Prognostic significance of peritumoral vessel invasion in clinical trials of adjuvant therapy for breast cancer with axillary lymph node metastasis. Human pathology. 1985 Dec 31; 16(12) :1212-8.

18. Contesso G, Mouriesse H, Friedman S, Genin J, Sarrazin D, Rouesse J. The importance of histologic grade in long-term prognosis of breast cancer: a study of 1,010 patients, uniformly treated at the Institut Gustave-Roussy. Journal of Clinical Oncology. 1987 Sep 1; 5(9):1378-86.

19. Franklin WA, Bibbo M, Doria MI, Dytch HE, Toth J, DeSombre E, Wied GL. Quantitation of estrogen receptor content and $\mathrm{Ki}-67$ staining in breast carcinoma by the microTICAS image analysis system. Analytical and quantitative cytology and histology. 1987 Aug; 9(4):279-86.

20. Stefano DD, Mingazzini PL, Scucchi L, Donnetti M, Marinozzi V. A comparative study of histopathology, hormone receptors, peanut lectin binding, ki-67 immunostaining, and nucleolar organizer region-associated proteins in human breast cancer. Cancer. 1991 Jan 15; 67(2):463-71.

21. Barbareschi M, Leonardi E, Mauri FA, Serio G, Dalla Palma P. p53 and c-erbB-2 protein expression in breast carcinomas. An immunohistochemical study including correlations with receptor status, proliferation markers, and clinical stage in human breast cancer. American journal of clinical pathology. 1992 Oct; 98(4):408-18.

22. Trihia H, Murray S, Price K, Gelber RD, Golouh R, Goldhirsch A, Coates AS, Collins J, CastiglioneGertsch M, Gusterson BA. Ki-67 expression in breast carcinoma: its association with grading systems, clinical parameters, and other prognostic factors--a surrogate marker? Cancer. 2003 Mar; 97(5):1321-31.

23. Ermiah E, Buhmeida A, Abdalla F, Khaled BR, Salem N, Pyrhönen S, Collan Y. Prognostic value of proliferation markers: immunohistochemical ki-67 expression and cytometric s-phase fraction of women with breast cancer in Libya. J Cancer. 2012 Jan 1; $3: 421-31$.

24. Jacquemier J, Charafe-Jauffret E, Monville F, Esterni B, Extra JM, Houvenaeghel G, Xerri L, Bertucci F, Birnbaum D. Association of GATA3, P53, Ki67 status and vascular peritumoral invasion are strongly prognostic in luminal breast cancer. Breast Cancer Res. 2009 Apr 30; 11(2):R23.

25. Nishimura R, Osako T, Okumura Y, Hayashi M, Toyozumi Y, Arima N. Ki-67 as a prognostic marker according to breast cancer subtype and a predictor of recurrence time in primary breast cancer. Experimental and therapeutic medicine. 2010 Sep 1; 1(5):747-54.

26. Midulla C, De Iorio P, Nagar C, Pisani T, Cenci M, Valli C, Nofroni I, Vecchione A. Immunohistochemical expression of p53, nm23-HI, Ki67 and DNA ploidy: correlation with lymph node status and other clinical pathologic parameters in breast cancer. Anticancer research. 1998 Dec; 19(5B):4033-37.

27. Kumaki N, Umemura S, Tang X, Saito Y, Suzuki Y, Tokuda Y. Alteration of immunohistochemical biomarkers between pre-and post-chemotherapy: hormone receptors, HER2 and Ki-67. Breast Cancer. 2011 Apr 1; 18(2):98-102.

28. Dowsett M, Smith IE, Ebbs SR, Dixon JM, Skene A, A'Hern R, Salter J, Detre S, Hills M, Walsh G. Prognostic value of Ki67 expression after short-term presurgical endocrine therapy for primary breast cancer. Journal of the National Cancer Institute. 2007 Jan 17; 99(2):167-70.

\section{How to cite this article?}

Jain R, Malik R, Trichal VK, Jain A, Bakna M. Immunohistochemical expression of Ki-67 in invasive breast carcinoma and its correlation with prognostic parameters. Int J Med Res Rev 2016;4(5):765-770.doi: 10.17511/ijmrr.2016.i05.17. 